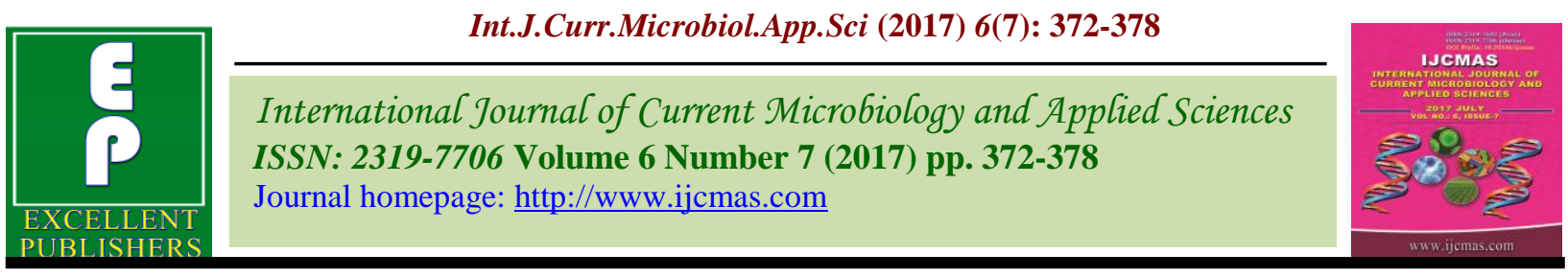

Original Research Article

https://doi.org/10.20546/ijcmas.2017.607.044

\title{
Character Association and Path Analysis for Seed Yield and its Components in Roselle (Hibiscus sabdariffa L.) in North Coastal Zone of Andhra Pradesh, India
}

\author{
N. Hari Satyanarayana ${ }^{1 *}$, V. Visalakshmi ${ }^{3}$, K.V. Ramana Murthy ${ }^{3}$, \\ K. Madhu Kumar', J. Jagannadham ${ }^{1}$, A. Upendra $\operatorname{Rao}^{3}$ and N. Venugopala Rao ${ }^{2}$ \\ ${ }^{1}$ Agricultural Research Station, Amadalavalasa, Srikakulam District, A. P. - 532 185, India \\ ${ }^{2}$ Regional Agricultural Research Station (North Coastal Zone), \\ Anakapalle, A.P. - 531 001, India \\ ${ }^{3}$ Agricultural Research Station, Ragolu, Srikakulam District, A. P. - 532 484, India \\ *Corresponding author
}

\section{A B S T R A C T}

Keywords

Correlation, Direct and indirect effects, North Coastal zone, Roselle, Seed yield.

Article Info

Accepted:

04 June 2017

Available Online:

10 July 2017
An experiment was conducted during kharif 2013 and 2014 in North Coastal Zone of Andhra Pradesh at Agricultural Research Station, Ragolu, Srikakulam district to study the character association among quantitative traits and their direct and indirect effects on seed yield in a set of 60 genotypes of roselle (Hibiscus sabdariffa L.). The quantitative traits pods plant ${ }^{-1}$, base diameter, seeds pod $^{-1}$, plant height, mid diameter, nodes plant ${ }^{-1}$ and test weight were found to be highly significant and positively correlated with the dependent variable, seed yield. Partitioning of phenotypic correlation coefficients of various components upon seed yield plant ${ }^{-1}$ into direct and indirect contributions revealed that pods plant ${ }^{-1}$ has maximum direct effect followed by seeds pod $^{-1}$ and test weight. Selection for characters viz., pods plant ${ }^{-1}$, seeds pod $^{-1}$, test weight, plant height and base diameter along with seed yield will be useful for improving seed yield in roselle.

\section{Introduction}

Roselle (Hibiscus sabdariffa L.) belongs to the family Malvaceae; native to Asia (India to Malaysia) or Africa; and is an annual or biennial plant cultivated in Tropical and SubTropical regions for its stem, fibres, edible calyces, leaves and seeds (Mahadevan et al., 2009). Roselle is a tetraploid species with $2 \mathrm{n}=4 \mathrm{x}=72$ (Sabiel et al., 2014) and proved its importance in fibre industries, preparation of medicines and in culinaries to make favourable dishes from its edible parts in many countries. Roselle fibre blended with jute is used in the manufacture of jute goods viz., cordage, sacking, hessian, canvas and rough sacks, ropes, twines, fishing nets etc. The stalks were used in making paper pulp, structural boards, as a blend for wood pulp and thatching huts (Juhi Agarwal and Ela Dedhia, 2014). Roselle seed oil is richer in carotenoids than expensive oils like niger and coriander seed oil (Ramada and Morsel, 2014). Carotenoids are important ingredients in cosmetic industries due to their antioxidant activity and protective effect on the skin 
(Platon, 1997). Roselle seed flour can prevent cancer, lower blood pressure and improve the digestive systems in humans (Karma and Chavan, 2017). Since, roselle is mostly used for its fibre in India, research efforts were made only on fibre yield and its contributing traits by researchers till date and there is every need to study on seed yield and its contributing characters as seed is also being used as raw material in many industries.

Generally, success of any crop improvement program largely depends on the magnitude of genetic variability within the traits, relationship between the traits and also direct and indirect contributions of these traits for the dependant variable, yield. Correlation and path coefficient analysis will help to identify component characters in a breeding programme whose selection would result in the improvement of complex traits that are positively correlated. Keeping this in view, this study was conducted for assessing the relationship between traits and evaluating the direct and indirect contributions of these traits to seed yield improvement in roselle.

\section{Materials and Methods}

Sixty roselle (Hibiscus sabdariffa L.) genotypes consisting of eleven exotic lines; four released varieties and 45 indigenous accessions were evaluated in North Coastal zone, Andhra Pradesh at Agricultural Research Station, Ragolu (Latitude $18^{\circ} 24^{\prime} \mathrm{N}$; Longitude $83.84^{\circ} \mathrm{E}$ at an altitude of $27 \mathrm{~m}$ above mean sea level) during early kharif seasons in 2013 and 2014. The experimental trial was laid out in randomized block design with a plot size of four rows of $2 \mathrm{~m}$ length in two replications with a spacing of $30 \times 10 \mathrm{~cm}$ under rainfed conditions. Recommended package of practices was followed to raise a good crop. Data on the basis of five randomly selected competitive plants were recorded on plant height $(\mathrm{cm})$, base diameter $(\mathrm{mm})$, mid diameter ( $\mathrm{mm}$ ), days to $50 \%$ flowering, pods plant $^{-1}$, seeds pod ${ }^{-1}$, test weight $(\mathrm{g})$ and seed yield plant $^{-1}(\mathrm{~g})$. Correlations were calculated as suggested by Johnson et al., (1955). The phenotypic correlations were used to find out the direct and indirect effects of the component characters on fibre yield per plant, according to Dewey and Lu (1959).

\section{Results and Discussion}

The analysis of variance revealed significant difference among the genotypes for all the nine characters studied (Table 1). Phenotypic (simple) correlation analysis is carried for all possible combination of characters to obtain information about relationship and intensity existing among them. Phenotypic correlation coefficients for different pairs of characters are given in table 2. In 2013, highly significant positive association of seed yield plant $^{-1}$ was observed with pods plant ${ }^{-1}$, seeds pod $^{-1}$, plant height and base diameter; whereas in 2014 the traits pods plant ${ }^{-1}$, test weight, mid diameter, base diameter and nodes plant $^{-1}$ were highly significant with positive association for seed yield ${ }^{-1}$. These results are in agreement with Dastidar et al., (1993), Islam et al., (2001), Palve et al., (2003), Echekwu and Showemino (2004), Ali and Sasmal (2006), Ibrahim and Hussein (2006), Pervin and Haque (2012), Ibrahim et al., (2013), Rupal et al., (2017) and Shiva Kumar et al., (2017). All the remaining traits were non-significant with the dependent variable seed yield and no variable was proved to be significant in a negative direction. This suggests selecting for the characters with high positive correlation would improve the seed yield in roselle.

Plant height exhibited significant positive association with base diameter, mid diameter, nodes plant ${ }^{-1}$, pods plant $^{-1}$ and seed yield plant $^{-1}$ for both the years, whereas, test weight showed highly significant negative 
association with plant height. Base diameter recorded positive significant association with plant height, mid diameter, nodes plant ${ }^{-1}$, pods plant $^{-1}$ and seed yield plant ${ }^{-1}$ for both years, whereas, days to $50 \%$ flowering showed significant positive relation in the year 2014 only.

Mid diameter exhibited positive significant association with plant height, base diameter, nodes plant ${ }^{-1}$ and pods plant ${ }^{-1}$, whereas, days to $50 \%$ flowering and seed yield plant $^{-1}$ showed significant positive relation in the year 2014 only. Nodes plant ${ }^{-1}$ exhibited significant positive association with plant height, base diameter, mid diameter and pods plant $^{-1}$, whereas, seed yield plant $^{-1}$ showed significant positive relation in the year 2014 only; however, days to $50 \%$ flowering showed significant negative association with nodes plant ${ }^{-1}$.

Days to $50 \%$ flowering exhibited significant positive correlation with plant height, base diameter, mid diameter and pods plant ${ }^{-1}$ in the year 2014 and negatively significant for test weight in both years.

Pods plant ${ }^{-1}$ exhibited significant positive correlation with all the traits except for test weight. By this it is evident that selection for these characters would increase the seed yield of roselle.

Seed $\operatorname{pod}^{-1}$ has significant positive association with plant height, pods plant ${ }^{-1}$ and seed yield in 2013 only and negative significant association was recorded with test weight in 2013 and 2014; whereas, it recorded nonsignificant association for rest of the quantitative traits.

Test weight recorded significant positive correlation with seed yield plant $^{-1}$ in 2014, whereas, showed significant negative association with plant height, days to $50 \%$ flowering, pods plant ${ }^{-1}$ and seeds pod ${ }^{-1}$. From inter-relationship studies it was evident that pods plant ${ }^{-1}$, seeds pod $^{-1}$, plant height, base diameter, test weight, mid diameter and nodes plant $^{-1}$ were having significant positive association for the trait seed yield, hence, selection for these characters is fruitful.

Partitioning of correlation coefficients for various component characters with seed yield into direct and indirect effects (Table 3) revealed that pods plant ${ }^{-1}(0.9038$ and 0.9169$)$ has maximum direct effect on seed yield followed by seeds $\operatorname{pod}^{-1}(0.3180$ and 0.2144$)$ and test weight $(0.2623$ and 0.2998$)$ which are in conformity with Dastidar et al., (1993), Islam et al., (2001), Echekwu and Showemino (2004), Pervin and Haque (2012) and Rupal et al., (2017).

High correlation coefficient of pods plant ${ }^{-1}$ (0.926 and 0.939) with seed yield was majorly due to its own direct effect; whereas, for seeds $\operatorname{pod}^{-1}(0.507$ in 2013) it was due to its own direct effects (0.3180) coupled with indirect effects through the trait pods plant ${ }^{-1}(0.2634)$. Similarly, high correlation coefficient of test weight (0.330 in 2014) with seed yield was majorly due to its own direct effect coupled with indirect effects through the trait pods plant $^{-1}$ (0.1109).

Plant height recorded high correlation coefficient (0.448) in 2013 which was due to the indirect effects through pods plant $^{-1}$ (0.4467) and seeds $\operatorname{pod}^{-1}(0.1008)$. Likewise, for base diameter $(0.330$ and 0.258$)$, significant correlation coefficients were majorly due to the indirect effects of pods plant $^{-1}(0.3569$ and 0.2496). Significant correlation coefficient for mid diameter in 2014 (0.269) was majorly due to the indirect effects through pods plant ${ }^{-1}(0.2070)$ coupled with its own direct effect (0.0485); similarly, for nodes plant ${ }^{-1}(0.248)$ in 2014, pods plant $^{-1}$ (0.2510) played significant role indirectly. 
Table.1 Analysis of variance for nine characters in roselle (Hibiscus sabdariffa L.) during 2013 and 2014

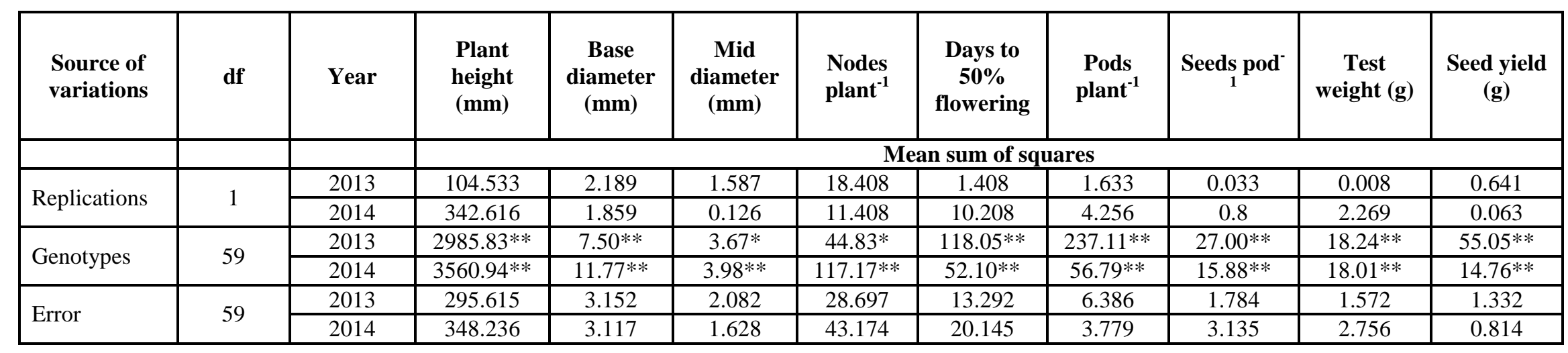

Table.2 Phenotypic correlation coefficients between seed yield and its component characters in roselle (Hibiscus sabdariffa L.) in 2013 and 2014

\begin{tabular}{|c|c|c|c|c|c|c|c|c|c|c|}
\hline \multicolumn{2}{|c|}{ Character } & $\begin{array}{l}\text { Plant height } \\
(\mathrm{cm})\end{array}$ & $\begin{array}{c}\text { Base diameter } \\
(\mathrm{mm})\end{array}$ & $\begin{array}{l}\text { Mid diameter } \\
(\mathrm{mm})\end{array}$ & Nodes / plant & $\begin{array}{c}\text { Days to } 50 \% \\
\text { flowering }\end{array}$ & $\begin{array}{c}\text { Pods per } \\
\text { plant }\end{array}$ & $\begin{array}{c}\text { Seeds per } \\
\text { pod }\end{array}$ & $\begin{array}{c}\text { Test weight } \\
\text { (g) }\end{array}$ & $\begin{array}{l}\text { Seed yield } \\
(\mathrm{g})\end{array}$ \\
\hline \multirow{2}{*}{ Plant height $(\mathrm{cm})$} & 2013 & 1.000 & $0.513 * *$ & $0.182 *$ & $0.310 * *$ & -0.017 & $0.494 * *$ & $0.317 * *$ & $-0.444 * *$ & $0.448 * *$ \\
\hline & 2014 & 1.000 & $0.729 * *$ & $0.651 * *$ & $0.464 * *$ & $0.383 * *$ & $0.219 *$ & 0.135 & $-0.329 * *$ & 0.139 \\
\hline \multirow{2}{*}{$\begin{array}{l}\text { Base diameter } \\
(\mathrm{mm})\end{array}$} & 2013 & & 1.000 & $0.238 * *$ & $0.279 * *$ & -0.064 & $0.395 * *$ & 0.100 & -0.142 & $0.330 * *$ \\
\hline & 2014 & & 1.000 & $0.826^{* *}$ & $0.509 * *$ & $0.234 * *$ & $0.272 * *$ & 0.138 & -0.089 & $0.258 * *$ \\
\hline \multirow{2}{*}{$\begin{array}{l}\text { Mid diameter } \\
\quad(\mathrm{mm})\end{array}$} & 2013 & & & 1.000 & $0.429 * *$ & -0.036 & $0.186^{*}$ & -0.022 & 0.038 & 0.160 \\
\hline & 2014 & & & 1.000 & $0.446 * *$ & $0.181 *$ & $0.226^{*}$ & 0.121 & 0.051 & $0.269 * *$ \\
\hline \multirow{2}{*}{ Nodes / plant } & 2013 & & & & 1.000 & $-0.197 *$ & $0.182^{*}$ & 0.040 & -0.070 & 0.162 \\
\hline & 2014 & & & & 1.000 & 0.143 & $0.274 * *$ & 0.066 & -0.027 & $0.248 * *$ \\
\hline \multirow{2}{*}{$\begin{array}{c}\text { Days to } 50 \% \\
\text { flowering }\end{array}$} & 2013 & & & & & 1.000 & -0.128 & 0.163 & $-0.234 *$ & -0.143 \\
\hline & 2014 & & & & & 1.000 & $0.186^{*}$ & -0.005 & $-0.262 * *$ & -0.084 \\
\hline \multirow{2}{*}{ Pods per plant } & 2013 & & & & & & 1.000 & $0.291 * *$ & $-0.287 * *$ & $0.926 * *$ \\
\hline & 2014 & & & & & & 1.000 & -0.059 & 0.121 & $0.939 * *$ \\
\hline \multirow{2}{*}{ Seeds per pod } & 2013 & & & & & & & 1.000 & $-0.306 * *$ & $0.507 * *$ \\
\hline & 2014 & & & & & & & 1.000 & $-0.400 * *$ & 0.043 \\
\hline \multirow{2}{*}{ Test weight (g) } & 2013 & & & & & & & & 1.000 & -0.102 \\
\hline & 2014 & & & & & & & & 1.000 & $0.330 * *$ \\
\hline \multirow{2}{*}{ Seed yield $(\mathrm{g})$} & 2013 & & & & & & & & & 1.000 \\
\hline & 2014 & & & & & & & & & 1.000 \\
\hline
\end{tabular}

*Significant at $5 \%$ level, **Significant at $1 \%$ level 
Table.3 Direct and indirect contributions of component characters for seed yield in roselle (Hibiscus sabdariffa L.) in 2013 and 2014

\begin{tabular}{|c|c|c|c|c|c|c|c|c|c|c|}
\hline \multicolumn{2}{|c|}{ Character } & \multirow{2}{*}{$\begin{array}{c}\text { Plant height } \\
(\mathrm{cm})\end{array}$} & \multirow{2}{*}{$\begin{array}{c}\text { Base } \\
\text { diameter } \\
(\mathrm{mm}) \\
-0.0210\end{array}$} & \multirow{2}{*}{$\begin{array}{c}\text { Mid } \\
\text { diameter } \\
(\mathrm{mm}) \\
-0.0018\end{array}$} & \multirow{2}{*}{$\begin{array}{c}\text { Nodes / } \\
\text { plant } \\
0.0011\end{array}$} & \multirow{2}{*}{$\begin{array}{c}\text { Days to } \\
\text { flowering } \\
0.0003\end{array}$} & \multirow{2}{*}{$\begin{array}{c}\text { Pods per } \\
\text { plant } \\
0.4467\end{array}$} & \multirow{2}{*}{$\begin{array}{c}\text { Seeds } \\
\text { per pod } \\
0.1008\end{array}$} & \multirow{2}{*}{$\begin{array}{c}\text { Test weight } \\
\qquad(\mathrm{g}) \\
-0.1165\end{array}$} & \multirow{2}{*}{$\begin{array}{c}\text { Correlation } \\
\text { with seed yield } \\
0.448^{* *}\end{array}$} \\
\hline Plant & 2013 & & & & & & & & & \\
\hline height & 2014 & 0.0098 & -0.0217 & 0.0316 & -0.0086 & -0.0040 & 0.2009 & 0.0290 & -0.0986 & 0.139 \\
\hline \multirow{2}{*}{$\begin{array}{c}\text { Base } \\
\text { diameter }\end{array}$} & 2013 & 0.0199 & -0.0410 & -0.0024 & 0.0009 & 0.0013 & 0.3569 & 0.0318 & -0.0373 & $0.330 * *$ \\
\hline & 2014 & 0.0072 & -0.0298 & 0.0401 & -0.0094 & -0.0024 & 0.2496 & 0.0296 & -0.0266 & $0.258 * *$ \\
\hline \multirow{2}{*}{$\begin{array}{c}\text { Mid } \\
\text { diameter }\end{array}$} & 2013 & 0.0071 & -0.0098 & -0.0099 & 0.0015 & 0.0007 & 0.1678 & -0.0072 & 0.0100 & 0.160 \\
\hline & 2014 & 0.0064 & -0.0246 & 0.0485 & -0.0082 & -0.0019 & 0.2070 & 0.0259 & 0.0154 & $0.269 * *$ \\
\hline \multirow{2}{*}{$\begin{array}{c}\text { Nodes / } \\
\text { plant }\end{array}$} & 2013 & 0.0120 & -0.0114 & -0.0043 & 0.0034 & 0.0038 & 0.1643 & 0.0129 & -0.0184 & 0.162 \\
\hline & 2014 & 0.0046 & -0.0152 & 0.0216 & -0.0185 & -0.0015 & 0.2510 & 0.0142 & -0.0080 & $0.248 * *$ \\
\hline \multirow{2}{*}{$\begin{array}{l}\text { Days to } \\
\text { flowering }\end{array}$} & 2013 & -0.0007 & 0.0026 & 0.0004 & -0.0007 & -0.0194 & -0.1160 & 0.0517 & -0.0614 & -0.143 \\
\hline & 2014 & 0.0038 & -0.0070 & 0.0088 & -0.0026 & -0.0104 & 0.1710 & -0.0011 & -0.0784 & -0.084 \\
\hline \multirow{2}{*}{$\begin{array}{c}\text { Pods per } \\
\text { plant }\end{array}$} & 2013 & 0.0192 & -0.0162 & -0.0018 & 0.0006 & 0.0025 & 0.9038 & 0.0927 & -0.0752 & $0.926 * *$ \\
\hline & 2014 & 0.0022 & -0.0081 & 0.0109 & -0.0051 & -0.0019 & 0.9169 & -0.0126 & 0.0363 & $0.939 * *$ \\
\hline \multirow{2}{*}{$\begin{array}{c}\text { Seeds per } \\
\text { pod }\end{array}$} & 2013 & 0.0123 & -0.0041 & 0.0002 & 0.0001 & -0.0032 & 0.2634 & 0.3180 & -0.0803 & $0.507 * *$ \\
\hline & 2014 & 0.0013 & -0.0041 & 0.0059 & -0.0012 & 0.0001 & -0.0538 & 0.2144 & -0.1199 & 0.043 \\
\hline \multirow{2}{*}{$\begin{array}{c}\text { Test } \\
\text { weight }(\mathrm{g})\end{array}$} & 2013 & -0.0172 & 0.0058 & -0.0004 & -0.0002 & 0.0046 & -0.2591 & -0.0974 & 0.2623 & -0.102 \\
\hline & 2014 & -0.0032 & 0.0026 & 0.0025 & 0.0005 & 0.0027 & 0.1109 & -0.0857 & 0.2998 & $0.330 * *$ \\
\hline
\end{tabular}

Bold: Direct effects, Residual effect: 2.34\% (2013) and 4.01\% (2014) 
The value of residual effects was low $(2.34 \%$ and $4.01 \%$ ) suggesting that most of the total variations for seed yield in roselle were explained. Finally, the path coefficient analysis revealed importance of pods plant ${ }^{-1}$, seeds $\operatorname{pod}^{-1}$ and test weight for their contribution either directly or indirectly to seed yield and hence, during selection these traits should be given utmost attention for developing of high seed yielding roselle varieties.

In conclusion, based on character association and path analysis studies seed yield plant $^{-1}$ may be improved by selection of tall plants coupled with high pods plant ${ }^{-1}$ having strong base and mid diameter with more number of seeds and high test weight.

\section{Acknowledgement}

The authors are highly thankful to the authorities of ANGRAU, Andhra Pradesh for providing necessary help and infrastructural facilities to undertake this study.

\section{References}

Ali, M.N. and Sasmal, B.G. 2006. Association of seed yield and its components in segregating population of tossa jute (Corchorus olitorius). Agric. Sci. Digest, 26(3): 206-208.

Dastidar, K.K.G., Agarwalla, K.K. and Roychowdhury P. 1993. Genetic variability and association component characters for seed yield in Olitorius jute. Indian J. Genet., 53(2): 157-160.

Dewey, D.R. and Lu, K.H. 1959. A correlation and path coefficient analysis of components of crested wheat grass seed production. Agron. J., 51: 515-518.

Echekwu, C.A. and Showemimo, F.A. 2004. Genetic, Phenotypic and environmental variances and character association in kenaf. African Crop Sci. J., 12(4): 321-
326.

Ibrahim, E.B., Abdel, W.H.A., Elshiekh, A.I. and Ahmed M.E.N. 2013. Interrelationship between yield and its components in some roselle (Hibiscus sabdariffa L.) genotyoes. World $J$. Agric. Res., 1(6): 114-118.

Ibrahim, M.M. and Hussein, R.M. 2006. Variability, heritability and genetic advance in some genotypes of roselle (Hibiscus sabdariffa L.). World J. Agric. Sci., 2(3): 340-345.

Islam, M.S., Uddin, M.N., Haque, M.M., Islam, M.N. 2001. Path coefficient analysis for some fibre yield related traits in white jute (Corchorus capsularis L.). Pakistan J Biological Sci. 4(1): 47-49.

Johnson, H.W., Robinson, H.F. and Comstock, R.F. 1955. Estimates of genetic and environmental variability in soybean. Agron. J., 47: 314-318.

Juhi Agarwal and Ela Dedhia 2014. Current scenario of Hibiscus sabdariffa (Mesta) in India (Maharastra). The Inter. J. Social Sci. Humanities Invention 1(3): 129-135.

Karma, B.R. and Chavan, U.D. 2017. Antioxidant Activity and Nutritional Value of Roselle Seeds Flour. Int. J. Curr. Microbiol. App. Sci., 6(4): 26542663.

Mahadevan, N., Shivali and Pradeep, K. 2009. Hibiscus sabdariffa Linn. - An overview. Natural Product Radiance 8(1): 77-83.

Palve, S.M. and Sinha, M.K. 2005. Genetic variation and interrelationships among fibre yield attributes in secondary genepool of Corchorus spp. SABRAO J. Breeding and Genetics, 37(1): 55-64.

Pervin, N., Haque G.K., 2012. Path coefficient analysis for fibre yield related traits in Deshi jute (Corchorus capsularis L.). IRJALS, 1(3): 72-77.

Platon, J.F. (1997). Lipids in Cosmetology. 
Ol. Corps. Gras. Lipid, 4: 275-281.

Ramadan, M.F. and Morsel, J.T. 2004. Oxidative stability of black cumin (Nigella sativa L.), coriander (Coriandrum sativum L.) and niger (Guizotia abyssinica Cass.) crude seed oils upon stripping. Eur. J. Lipid Sci. Technol., 106: 35-43.

Rupal, D., Modha, K.G., Dhirendra Kumar and Meenakshi Dhoot. 2017. Correlations and Path analysis studies on yield and its components in Mungbean (Vigna radiata (L.) Wilczek). Int. J. Curr. Microbial. App. Sci. 6(5): 370-378.
Sabiel, S.A.I., Ismail, M.I., Osman, A. and Sun, D. 2014. Genetic variability for yield and related attributes of roselle (Hibiscus sabdariffa L.) genotypes under rainfed condition in a Semi-arid zone of Sudan. Persian Gulf Crop Protection 3(1): 33-40.

Shiva Kumar, K., Nidagundi, J.M. and Hosamani, A.C. 2017. Correlation analysis for Agro-Morphological Features in Upland Cotton under rainfed conditions. Int. J. Curr. Microbiol. App. Sci. 6(5): 2593-2596.

\section{How to cite this article:}

Hari Satyanarayana, N., V. Visalakshmi, K.V. Ramana Murthy, K. Madhu Kumar, J. Jagannadham, A. Upendra Rao and Venugopala Rao, N. 2017. Character Association and Path Analysis for Seed Yield and its Components in Roselle (Hibiscus sabdariffa L.) in North Coastal Zone of Andhra Pradesh, India. Int.J.Curr.Microbiol.App.Sci. 6(7): 372-378. doi: https://doi.org/10.20546/ijcmas.2017.607.044 